\title{
Implementasi Sistem Informasi Pelayanan Kesehatan Pada Klinik Smart Medica
}

\author{
Rahayu Amalia ${ }^{[1]^{*}}$, Nurul Huda ${ }^{[2]}$ \\ Fakultas Ilmu Komputer, Universitas Bina Darma ${ }^{[1],[2]}$ \\ Jalan A. Yani no.3 Palembang, Indonesia \\ rahayu_amalia@binadarma.ac.id ${ }^{[1]}$,nurul_huda@binadarma.ac.id ${ }^{[2]}$
}

\begin{abstract}
The clinic is one of the public services engaged in the health sector which is inseparable from the development of information technology. Smart Medica Clinic in data processing is still done manually where information about the Smart Medica clinic is difficult to obtain, such as information about the doctor and also the doctor's schedule on duty while the Smart Medica clinic is one of the largest clinics in Sekayu Regency and also already famous and has many patients. With this situation, webbased information systems are built so that services to the community can be comprehensive and the Smart Medica Clinic can provide information that is needed by patients up to date and also patient satisfaction is fulfilled. This information system was built using the WaterFall method, using the PHP programming language and the My Sql database.
\end{abstract}

Keywords - Information Systems, Website, Water Fall, PHP, My Sql

Abstrak- Klinik merupakan salah satu pelayanan publik yang bergerak di bidang kesehatan yang tak terlepas dari perkembangan teknologi informasi. Klinik Smart Medica dalam pengolahan datanya masih di lakukan secara manual dimana informasi-informasi seputar klinik smart medica sulit di dapat, seperti informasi mengenai dokter dan juga jadwal dokter yang bertugas sedangkan klinik smart medica ini merupakan salah satu klinik terbesar yang ada di kabupaten sekayu dan juga sudah terkenal serta memiliki banyak pasien. Hasil dari penelitian ini yaitu Sistem Informasi berbasis web agar pelayanan kepada masyarakat dapat menyeluruh dan Klinik Smart Medica dapat memberikan informasi-informasi yang di butuhkan oleh pasien secara up to date dan juga kepuasan pasien pun jadi terpenuhi. Sistem informasi ini dibangun menggunakan metode WaterFall, menggunakan bahasa perograman PHP dan database My Sql. Sql

Kata Kunci-Sistem Informasi, Website, WaterFall, PHP, My

\section{PENDAHULUAN}

Klinik merupakan salah satu pelayanan publik yang bergerak di bidang kesehatan[1] yang tak terlepas dari perkembangan teknologi informasi. dimana perkembangan teknologi informasi semakin hari semakin canggih dan cepat, tidak kalah juga dalam dunia medis teknologi sangat di butuhkan, contohnya pada pendataan atau pendaftaran pasien, dan informasi-informasi lain yang memberikan dampak baik bagi pengguna teknologi. Semakin tinggi tingkat pelayanan yang diberikan suatu klinik kepada pasien maka semakin tinggi pula tingkat terpenuhinya kepuasan pasien [2]. Klinik Smart Medica ini merupakan klinik yang sudah ternama dan banyak sekali dikunjungi pasien baik dari dalam daerah maupun luar daerah, karena memiliki kualitas yang baik serta pelayanan yang sangat bagus dan biaya rawat jalan maupun rawat inap yang terjangkau untuk masyarakat. Klinik Smart Medica dalam pengolahan datanya masih di lakukan secara manual dimana informasi-informasi seputar klinik smart medica sulit di dapat, seperti informasi mengenai dokter dan juga jadwal dokter yang bertugas sedangkan klinik smart medica ini merupakan salah satu klinik terbesar yang ada di kabupaten sekayu dan juga sudah terkenal serta memiliki banyak pasien.

Dengan situasi dan kondisi seperti ini dan juga semakin majunya teknologi informasi tidak membuat klinik smart medica menjadi putus harapan tinggal bagaimana klinik ini menyelesaikan solusinya. berbagai strategi pun harus di jalankan salah satunya yaitu dengan mengikuti perkembangan teknologi informasi itu sendiri yaitu dengan membuat suatu sistem informasi berbasis website. Sistem Informasi merupakan suatu elemen yang saling berhubungan antara satu dengan yang lain dan membentuk satu kesatuan menjadi suatu informasi yang berguna dalam mengambil suatu keputusan[3]. Sedangkan website merupakan salah satu solusi bagi persaingan bisnis dimana dengan memiliki website dapat menjalankan bisnis secara global, informasi-informasi pun bisa di dapatkan dengan mudah[4]. Dengan di implementasikannya sistem informasi ini maka Klinik Smart Medica dapat memberikan informasi-informasi yang di butuhkan oleh pasien secara up to date dan juga kepuasan pasien pun jadi terpenuhi.

\section{TINJAUAN PUSTAKA \\ A. Sistem Informasi \\ Sistem informasi adalah suatu sistem didalam suatu organisasi yang mempertemukan kebutuhan pengolahan}


transaksi harian yang mendukung fungsi organisasi yang bersifat manajeral dengan kegiatan strategi dari suatu organisasi untuk dapat menyediakan laporan-laporan yang diperlukan oleh pihak luar tertentu[5]. Sistem informasi merupakan sistem yang menyediakan informasi dengan cara sedemikian rupa sehingga bermanfaat bagi penerima. Secara lebih detil, sistem informasi dapat didefinisikan sebagai seperangkat entitas yang terdiri dari hardaware, software dan brainware yang saling bekerjasama untuk menyediakan data yang diolah sehingga berguna dan bermanfaat bagi penerima data tersebut[6].

\section{B. Pelayanan}

Pelayanan adalah pemberian jasa baik oleh pemerintah, pihak swasta atas nama pemerintah ataupun pihak swasta kepada masyarakat, dengan atau tanpa pembayaran guna memenuhi kebutuhan dan kepentingan masyarakat. Pelayanan juga merupakan suatu kegiatan atau urutan kegiatan yang terjadi dalam interaksi langsung antara seseorang dengan orang lain atau mesin secara fisik, dan menyediakan kepuasan pelanggan[7].

\section{Website}

Website atau disingkat web, dapat diartikan sekumpulan halaman yang terdiri dari beberapa laman yang berisi informasi dalam bentuk data digital baik berupa text, gambar, video, audio dan animasi lainnya yang disediakan melalui jalur koneksi internet[8] .

\section{My Sql}

SQL (Structure Query Language) ialah sebuah terobosan baru dari Microsoft dalam bidang database. SQL server adalah sebuah DBMS (Database Management System) yang dibuat oleh Microsoft untuk berkecimpung dalam persaingan dunia pengolahan data menyusul pendahulunya seperti IBM dan Oracle[9].

\section{E. Penelitian Terdahulu}

Berdasarkan penelitian terdahulu yang berjudul Rancang Bangun Sistem Informasi Klinik Praktik Dokter Berbasis Web dengan menerapkan konsep sistem informasi klinik dokter praktik berbasis web untuk mengelolah data pasien, data dokter, data obat, data tindakan dan data rekam medis dengan bantuan komputer, sejak dari pasien datang untuk berobat, pencatatan riwayat penyakit (Rekam medis) pasien, hingga pendataan persediaan obat, untuk pengambilan keputusan dan pemeliharaan basis data. Sistem Informasi yang dirancang dengan menggunakan pemrograman PHP dan MySQL sebagai databasenya dapat menjadi solusi atas permasalahan yang dihadapi[10].

Sedangkan pada Sistem Informasi Administrasi Pasien Pada Klinik Keluarga Depok berpendapat bahwa demi tercapainya suatu pelayanan kesehatan yang baik, klinik harus ditunjang oleh sistem yang berkualitas yang mampu mengatur dan mengelola data-data yang akan dijadikan sumber informasi. Banyaknya variabel pada klinik turut menentukan kecepatan arus informasi yang dibutuhkan oleh petugas dan pasien. Sistem administrasi pasien yang ada pada Klinik Keluarga masih dilakukan secara konvensional atau masih menggunakan media kertas, mulai dari pengelolaan data pasien, rekam medis, transaksi pembayaran hingga pembuatan laporan-laporan, sehingga memiliki resiko untuk rusak atau hilang. Pada mulanya hal itu bukanlah suatu masalah bagi pihak klinik, namun di saat jumlah pasien per harinya semakin banyak maka pihak klinik saat ini mulai merasa kewalahan dalam mengatur data-data mengenai pasien dan perekapan administrasi keuangan. Perancangan program merupakan solusi terbaik untuk memecahkan permasalahan yang ada pada klinik ini. Dengan adanya perancangan sistem informasi klinik diharapkan dapat mempermudah petugas klinik dalam melakukan tugas-tugasnya dengan lebih efektif dan efisien dibandingkan dengan sistem sebelumnya dalam mewujudkan pelayanan kesehatan yang prima. Metode pengembangan sistem yang diterapkan pada program administrasi pasien ini menggunakan waterfall dimulai dari analisis, desain, pengkodean, pengujian, dan tahap pendukung sehingga menghasilkan sistem informasi yang terkomputerisasi sehingga mempercepat proses pengolahan data, efisiensi dalam manajemen biaya serta informasi yang dihasilkan lebih akurat[11].

Menurut jurnal Sistem Informasi Pelayanan Kesehatan Pada Klinik Medika Antapani Bandung, dimana permasalahan yang terjadi yaitu dalam melakukan pengolahan data pasien, rekam medis pasien, transaksi pembayaran pengobatan, pengelolaan data obat, dan dalam pembuatan laporan dari satu bagian ke bagian lain masih kurang terkontrol dengan baik. Metode pengembangan sistem yang digunakan Waterfall. Metode Analisis menggunakan terstruktur yang terdiri dari Flowmap, Diagram Konteks, DFD, Kamus data, Noramalisasi, ERD, dan Relasi tabel. Sedangkan hasil dari pembuatan aplikasi Sistem Informasi Pelayanan kesehatan ini adalah pengolahan data pasien, rekam medis pasien, dan transaksi pembayaran menjadi lebih mudah. Proses pencarian data pasien, rekam medis pasien, dan pembuatan laporan menjadi lebih mudah karena tersimpan dalam sebuah database[12].

Jurnal berjudul Pembuatan Sistem Informasi Pelayanan Kesehatan Masyarakat Berbasis Web Mapping (Studi Kasus: Kabupaten Sukoharjo, Provinsi Jawa Tengah). Kabupaten Sukoharjo merupakan salah satu kabupaten yang terdapat di Provinsi Jawa Tengah. Sebagai kabupaten yang sedang berkembang, Kabupaten Sukoharjo setiap tahunnya mengalami peningkatan jumlah penduduk. Dengan adanya peningkatan jumlah penduduk tersebut maka kebutuhan penduduk terkait informasi pelayanan kesehatan masyarakat juga akan meningkat. Hal ini dikarenakan masyarakat semakin sadar dan percaya bahwa kesehatan merupakan aset utama dalam kehidupan sehari - hari. Namun sangat disayangkan, hingga saat ini jenis informasi pelayanan kesehatan yang tersedia hanya sebatas data non spasial saja dan terbatas. Tidak tersedianya gambaran secara geografis yang jelas dan informasi yang lengkap tentang keadaan dan penyebaran pelayanan kesehatan masyarakat di Kabupaten Sukoharjo. 
Dengan dibuatnya sistem informasi pelayanan kesehatan masyarakat di Kabupaten Sukoharjo berbasis web mapping diharapkan mampu memberikan solusi atas masalah yang dihadapi tersebut dengan penyajian informasi terintegrasi dari data spasial dan non spasial serta dapat memberikan kemudahan bagi siapapun dalam mengakses informasi layanan kesehatan di Kabupaten Sukoharjo. Untuk dapat menghasilkan sistem informasi berbasis web mapping ini dibutuhkan data spasial beserta data non spasialnya atau data atributnya dari masing - masing lokasi pelayanan kesehatan seperti rumah sakit, puskesmas, klinik, dan apotek. Software yang digunakan untuk membangun sistem informasi berbasis web mapping dalam penelitian ini adalah ArcGIS dan Mango Map. Hasil penelitian ini berupa halaman web yang dipublish dengan menggunakan Wix hingga menghasilkan halaman web yang berisi tampilan peta yang menunjukkan informasi persebaran dan rasio ketersediaan pelayanan kesehatan masyarakat berupa rumah sakit, puskesmas, klinik dan apotek di Kabupaten Sukoharjo. Rasio ketersediaan pelayanan kesehatan adalah rasio yang menggambarkan penyediaan fasilitas pelayanan kesehatan. Rasio ini berupa perbandingan antara jumlah penduduk dengan jumlah sarana pelayanan kesehatan. Kata kunci : Pelayanan Kesehatan Masyarakat, Web Mapping, Mango Map, Wix[13].

Sedangkan Jurnal Berjudul Pengembangan sistem informasi pelayanan kesehatan pada klinik dokter keluarga Suradita: studi kasus desa Suradita Kec.Cisauk Tangerang. Klinik Dokter Keluarga Suradita merupakan sebuah klinik yang memberikan pelayanan kesehatan pada masyarakat Desa Suradita khususnya. Untuk meningkatkan pelayanan yang lebih baik terhadap pasien yang berobat diperlukan suatu penanganan dan pengolahan data yang baik dalam usaha yang sedang berkembang. Dari hasil analisis yang dilakukan, pada sistem berjalan yang selama ini digunakan oleh bagian pendaftaran dan bagian kasir kurang memadai dan kurang menunjang akan kebutuhan sistem yang diinginkan. Didalam memberikan pelayanannya kepada pasien, Klinik Dokter Keluarga Suradita masih menggunakan sistem manual dalam pengadministrasiannya, yang meliputi penulisan, penginputan, penyimpanan data pasien, Biaya pembayaran pasien, serta laporan-laporan yang diinginkan seperti laporan data pasien yang berobat, laporan data diagnosa pasien. Untuk mengatasi persoalan tersebut diatas, maka diperlukan suatu sistem informasi berbasis komputer. Dimana dalam penelitian ini perancangan sistem yang digunakan menggunakan metodologi SDLC serta dibuat pemrograman dengan Visual Basic 6.0 dan Microsoft Access 2003 sebagai basis datanya.[14]

Pembuatan Sistem Informasi Klinik Rawat Inap Prima Husada Widoro Pacitan Berbasis Website. Pengelolaan data secara konvensional, mempunyai banyak kelemahan, selain membutuhkan waktu yang lama. Dengan dukungan teknologi informasi yang ada sekarang ini, pekerjaan pengelolaan data dengan konvensional dapat digantikan dengan suatu sistem informasi dengan menggunakan komputer. Selain lebih cepat dan mudah, pengelolaan data juga menjadi lebih akurat, sehingga dapat membantu petugas untuk pengelolaan data pasien, data dokter, data perawat dan data jadwal jaga. Rumah sakit Klinik Rawat Inap Prima Husada Pacitan merupakan salah satu institusi pelayanan umum yang membutuhkan keberadaan suatu sistem informasi yang akurat, serta cukup memadai untuk meningkatkan pelayanannya kepada para pasien serta lingkungan yang terkait lainnya. Dengan lingkup pelayanan yang begitu luas, dan peoses pengerjaannya masih menggunakan sistem konvensional, tentunya banyak sekali permasalahan kompleks yang terjadi dalam proses pelayanan di Klinik Rawat Inap. Tujuan penelitian ini adalah merancang dan membuat Sistem Informasi Di Klinik Rawat Inap Prima Husada Pacitan yang digunakan untuk membantu petugas dalam mengelola data-data pasien, data dokter yang menangani pasien, data jadwal jaga yang ada pada Klinik Rawat Inap Prima Husada. Manfaat penelitian ini untuk memberikan kemudahan terhadap petugas untuk pengelolaan data pasien, data dokter dan data jadwal jaga, sehingga pencarian data akan lebih cepat tertangani. Dengan adanya Pembuatan sistem informasi Klinik Prima Husada berbasis website maka pihak Klinik dapat terbantu dalam pendatan dan penyimpanan data[15].

\section{METODE PENELITIAN}

Adapun metode yang digunakan dalam penelitian ini yaitu metode WaterFall[16]. Metode Water Fall di kenal dengan sebutan alur hidup klasik ( Clasic Life Cycle) . Adapun tahaptahapnya seperti dibawah ini

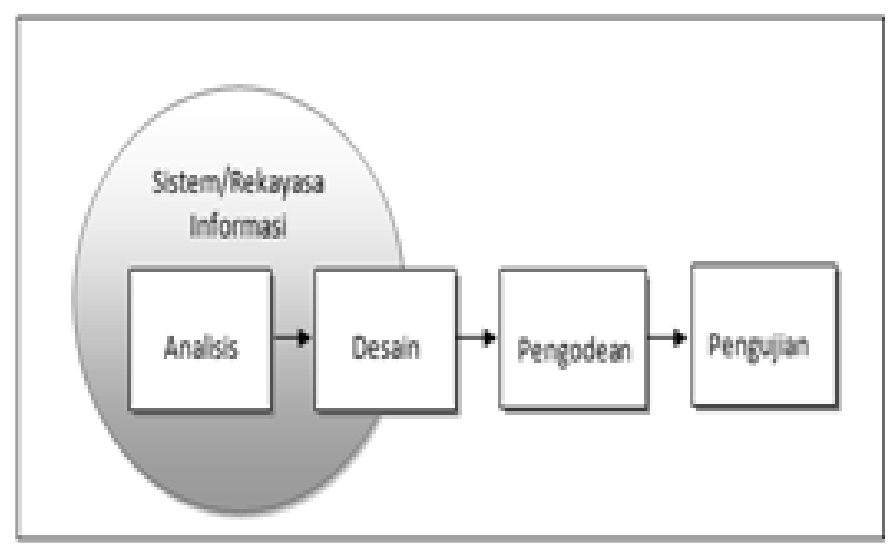

Gambar 1. Metode WaterFall

\section{A. Tahap Analisis ( Analysis)}

Yang dilakukan pada tahap ini yaitu menganalisa kebutuhan yang apa saja terkait Sistem Informasi yang akan di buat pada Klinik Smart Medika

\section{B. Tahap Disain (Design)}

Setelah di ketahui kebutuhan apa saja yang di perlukan untuk membuat sistem informasi ini maka langkah selanjutnya yaitu menganalisisnya, dengan cara mengetahui apa yang harus dilakukan oleh sistem lalu mendisain sistem yang akan di buat seperti Usecase, dan Activity Diagram disain database 


\section{Tahap Pengkodean (Coding)}

Setelah di disain sistem Informasi ini maka tahap selanjutnya yaitu pembuatan coding program atau aplikasi yang akan di buat

\section{Tahap Pengujian}

Setelah sistem sudah di buat maka di lakukan pengujian terhadap sistem ini apakah sudah sesuai dengan keinginan user

\section{E. Tahap selanjutnya yaitu Tahap Penerapan (Implementation)}

Setelah sistem di lakukan pengujian dan langkah terakhir yaitu mengimplementasikannya pada Klinik Smart Medica

\section{HASIL DAN PEMBAHASAN}

Hasil yang didapat pada penelitian ini yaitu Sistem Informasi Pelayanan Kesehatan pada Klinik Smart Medica. Berdasarkan metode yang dipakai maka tahap awal dari penelitian ini yaitu :

\section{A. Menganalisis Sistem}

Pada tahap ini peneliti menganalisis kebutuhan user, apa sebenarnya kebutuhan user, sistem seperti apa yang harus dibuat, data apa saja yang dibutuhkan dalam menunjang sistem ini, Setelah dilakukan analisis kepada bagian klinik dan juga pasien ternyata pasien sering tidak tahu jadwal dokter yang sering mereka konsultasi dalam berobat dikarenakan jadwal dokter tersebut sering di rooling dan tidak tetap, sedangkan terkadang pasien terebut di haruskan untuk konsultasi lebih lanjut dalam waktu satu minggu kemudian dan jika dokternya terus menerus berganti pasien menjadi khawatir apakah obatobatan dan juga rekam medis nya nanti akurat dan juga biasanya lain dokter lain pula penangannya.

\section{B. Merancang Sistem}

Untuk merancang sistem informasi ini peneliti menggunakan Uml ( Unified Modeling Language) yang merupakan teknik pemrograman beorientasi objek yang merupakan bahasa pemodelan untuk membangun perangkat lunak yang ber standarisasi [17]. UML yang di rancang terdari dari :

\section{1) Use Case Diagram}

Berikut adalah gambaran mengenai sistem yang akan dibuat seperti gambar 2 dibawah ini :

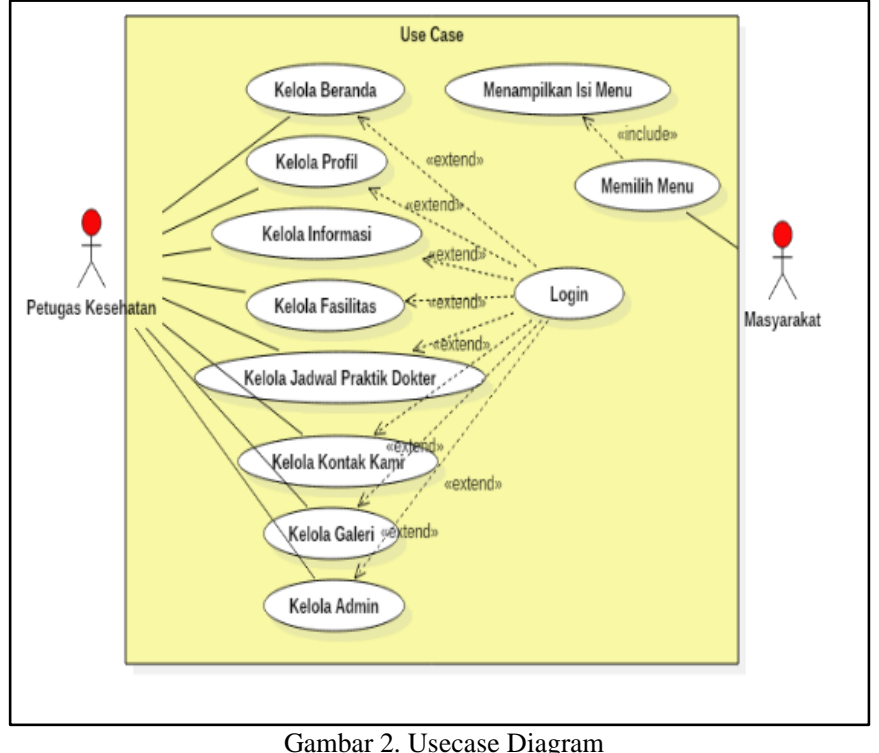

\section{2) Class Diagram}

Class diagram ini terdapat 3 tabel yang saling berelasi, yaitu tabel admin, tabel galeri dan tabel tbl_dokter.

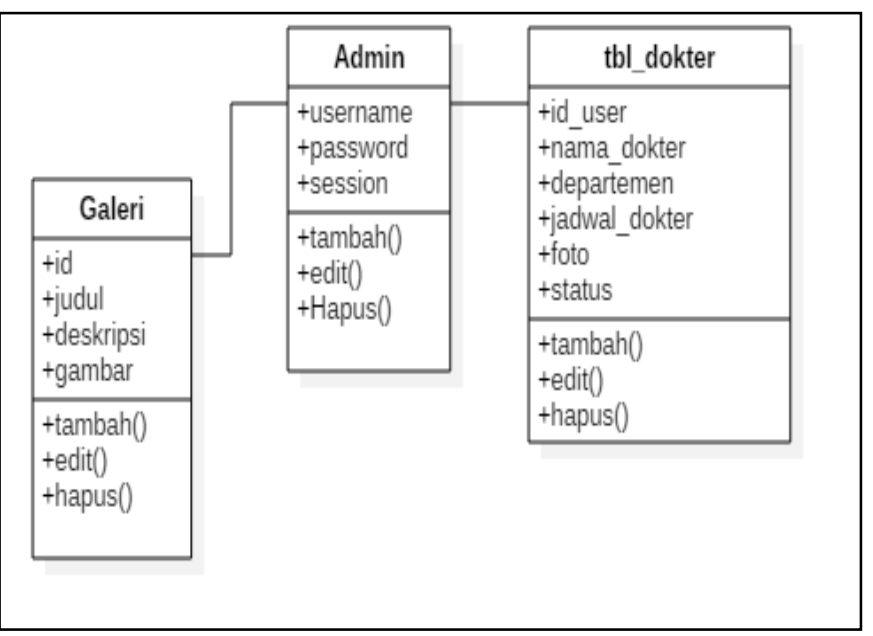

Gambar 3. Class Diagram

\section{3) Disain Basis Data}

Perancangan tabel ini bertujuan untuk mempermudah mengetahui field-field yang dibutuhkan dalam pembuatan tabel.

TABLE I. BASIS DATA ADMIN

\begin{tabular}{|c|l|c|c|c|}
\hline No & \multicolumn{1}{|c|}{ Field } & Type & Size & Keterangan \\
\hline 1. & id_username & varchar & 35 & Primary key \\
\hline 2. & password & varchar & 35 & \\
\hline 3. & Session & varchar & 35 & \\
\hline
\end{tabular}




\begin{tabular}{l}
\multicolumn{9}{c}{ TABLE II. } \\
\begin{tabular}{|c|l|c|c|c|}
\hline No & \multicolumn{1}{|c|}{ Field } & Type & Size & Ket \\
\hline 1. & id & int & 11 & Primary Key \\
\hline 3. & judul & text & - & \\
\hline 4. & deskripsi & text & - & \\
\hline 5. & gambar & text & - & \\
\hline
\end{tabular}
\end{tabular}

TABLE III. BASIS DATA JADWAL DOKTER

\begin{tabular}{|c|l|c|c|c|}
\hline No & Field & Type & Size & Ket \\
\hline 1 & Id User & Int & 11 & Primary Key \\
\hline 2 & Nama Dokter & Varchar & 30 & \\
\hline 3 & Departemen & Varchar & 30 & \\
\hline 4 & Jadwal Praktek & Varchar & 50 & \\
\hline 5 & Foto & Text & - & \\
\hline 6 & Status & Varchar & 9 & \\
\hline
\end{tabular}

\section{Pengkodean}

\section{1) Tampilan Halaman Menu Beranda}

Menu Beranda merupakan halaman awal ketika user mengakses website Klinik Smart Medica Sekayu. Tampilan Beranda ini menampilkan sambutan dari pimpinan Klinik Smart Medica Sekayu seperti pada gambar berikut.

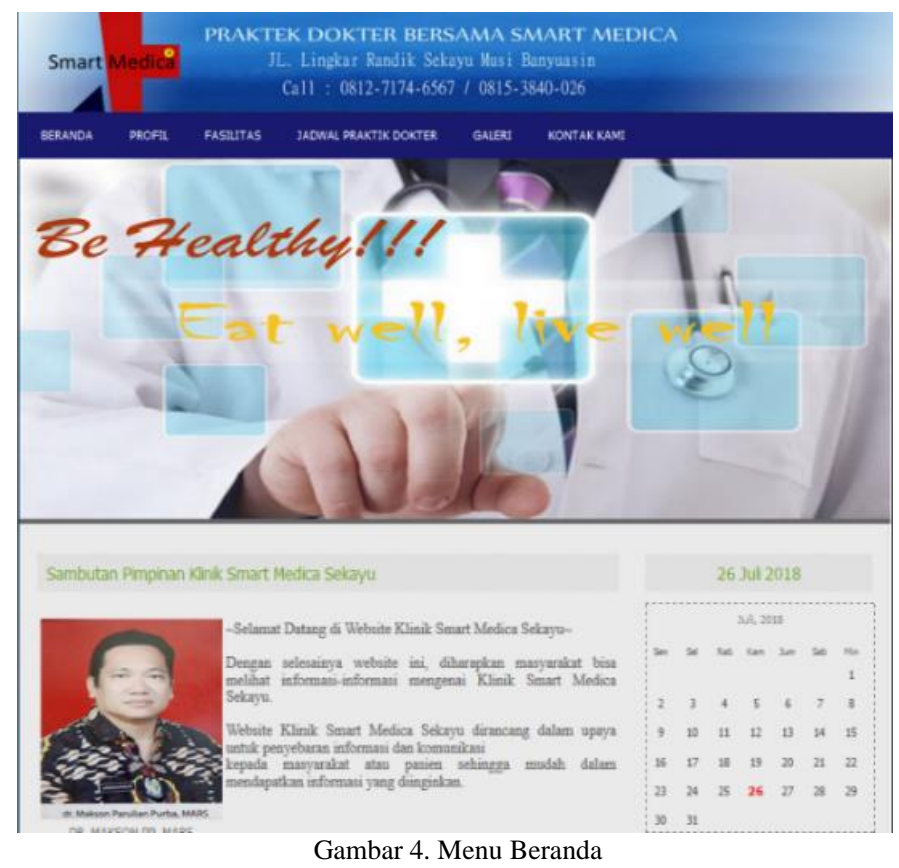

2) Tampilan Halaman Menu Profil

Menu Profil terdapat submenu atau dropdown, yaitu submenu sejarah, visi misi dan struktur organisasi.

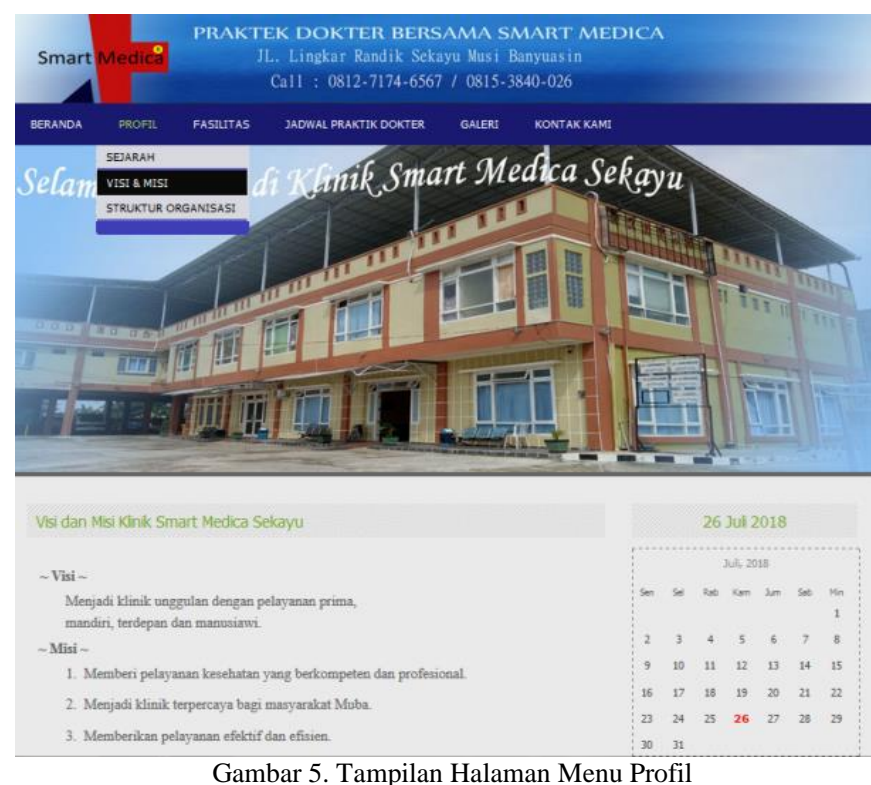

Gambar 5. Tampilan Halaman Menu Profil

3) Tampilan Halaman Menu Fasilitas

Menu Fasilitas menampilkan fasilitas yang ada dari Klinik Smart Medica Sekayu dan apabila salah satu gambar di klik akan menampilkan gambar yang lebih besar dan deskripsi gambar seperti gambar berikut :

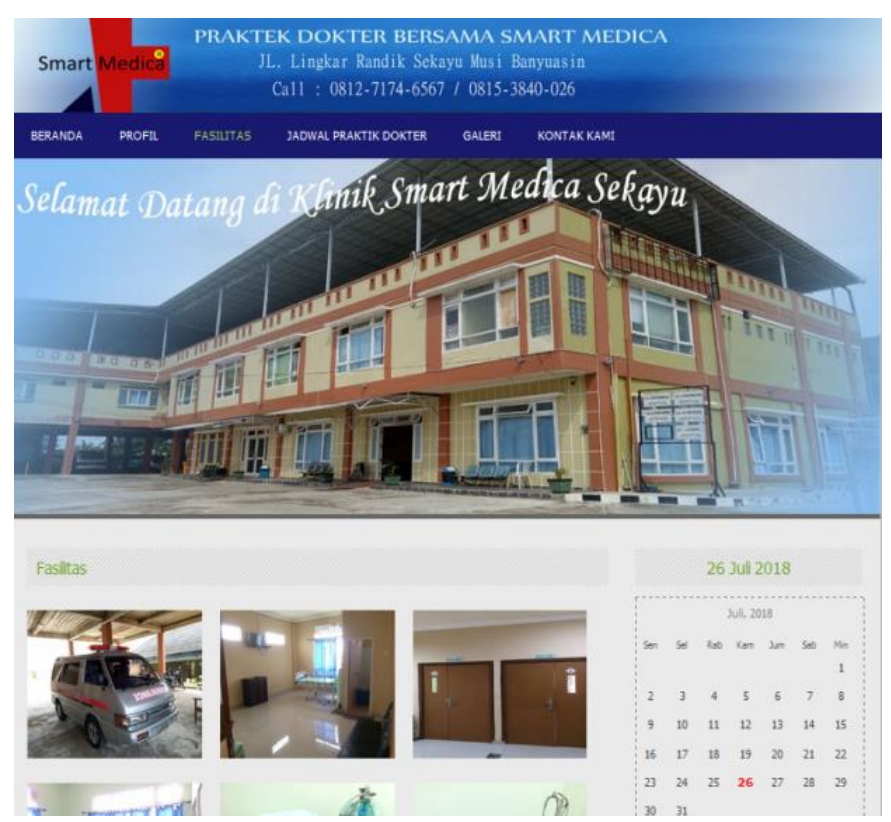

Gambar 6. Tampilan Halaman Menu Fasilitas

4) Tampilan Halaman Menu Jadwal Praktik Dokter

Menu Jadwal Praktik Dokter ini menampilkan jadwal praktik dokter sehingga user bisa mengetahui jadwal dokter yang diinginkan dari Klinik Smart Medica Sekayu seperti pada gambar berikut : 


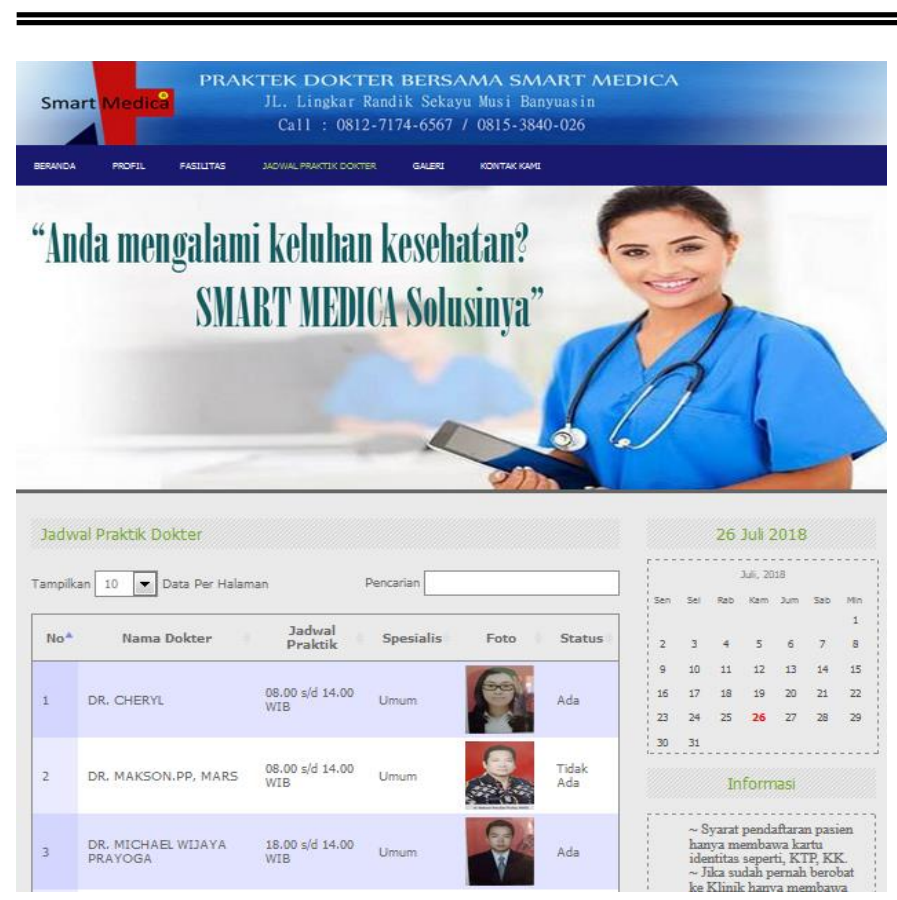

Gambar 7. Tampilan Halaman Menu Jadwal Praktik Dokter

5) Tampilan Halaman Login Admin

Dibawah ini merupakan tampilan halaman login admin, terlebih dahulu admin harus memasukkan username dan password yang valid dengan yang ada di database. Apabila username dan password salah akan muncul tampilan seperti login awal.

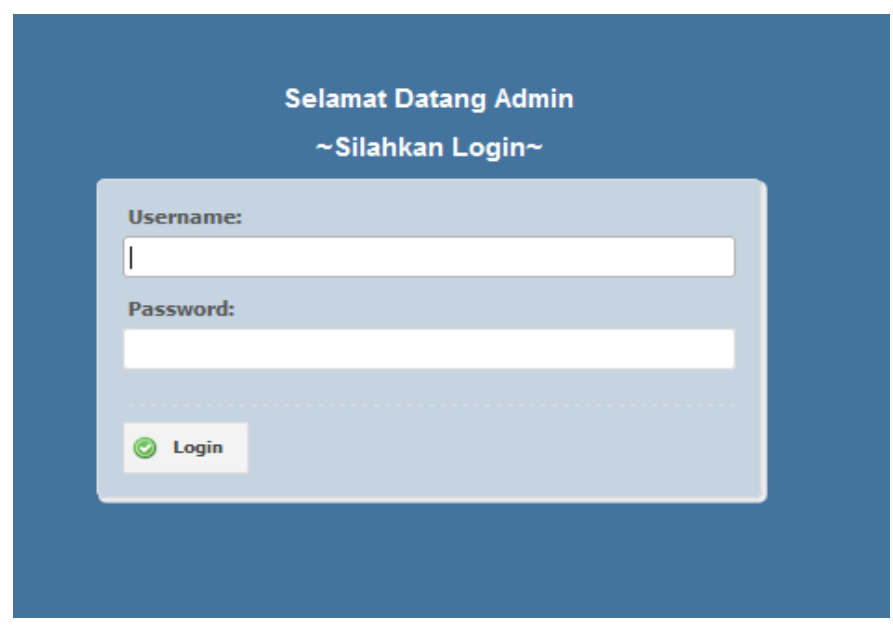

Gambar 8. Tampilan Halaman Login Admin

\section{Pengujian}

Teknik pengujian yang digunakan dalam penelitian ini adalah pengujian blackbox[18]. Pengujian blackbox menitikberatkan pada fungsi sistem. Teknik ini digunakan untuk mengetahui apakah perangkat lunak berfungsi dengan benar. Hasil pengujian sistem menggunakan teknik blackbox dapat dilihat pada tabel 5 .
TABLE IV

PENGUJian BLACK BoX

\begin{tabular}{|c|c|c|c|c|}
\hline No & Pengujian & $\begin{array}{l}\text { Hasil yang } \\
\text { diharapkan }\end{array}$ & Hasil pengujian & Kesimpulan \\
\hline 1 & Login & $\begin{array}{l}\text { Menampilkan } \\
\text { menu utama }\end{array}$ & $\begin{array}{l}\text { Sistem } \\
\text { menampilkan menu } \\
\text { utama }\end{array}$ & diterima \\
\hline 2 & $\begin{array}{l}\text { Simpan } \\
\text { data } \\
\text { Dokter }\end{array}$ & $\begin{array}{l}\text { Sistem } \\
\text { menampilkan } \\
\text { form data Dokter }\end{array}$ & $\begin{array}{l}\text { Sistem } \\
\text { menampilkan form } \\
\text { data Dokter }\end{array}$ & diterima \\
\hline 3 & $\begin{array}{l}\text { Edit data } \\
\text { Dokter }\end{array}$ & $\begin{array}{l}\text { Sistem } \\
\text { menampilkan } \\
\text { form data Dokter }\end{array}$ & $\begin{array}{l}\text { Sistem } \\
\text { menampilkan form } \\
\text { data Dokter }\end{array}$ & diterima \\
\hline 4 & $\begin{array}{l}\text { Simpan } \\
\text { data } \\
\text { Jadwal }\end{array}$ & $\begin{array}{l}\text { Sistem } \\
\text { menampilkan } \\
\text { form data Jadwal }\end{array}$ & $\begin{array}{l}\text { Sistem } \\
\text { menampilkan form } \\
\text { data Jadwal }\end{array}$ & diterima \\
\hline 5 & $\begin{array}{l}\text { Edit data } \\
\text { Jadwal }\end{array}$ & $\begin{array}{l}\text { Sistem } \\
\text { menampilkan } \\
\text { form data Jadwal }\end{array}$ & $\begin{array}{l}\text { Sistem } \\
\text { menampilkan form } \\
\text { data Jadwal }\end{array}$ & diterima \\
\hline 6 & $\begin{array}{l}\text { Pencarian } \\
\text { data }\end{array}$ & $\begin{array}{l}\text { Sistem } \\
\text { menampilkan data } \\
\text { Jadwal }\end{array}$ & $\begin{array}{l}\text { Sistem } \\
\text { menampilkan data } \\
\text { Jadwal yang dicari }\end{array}$ & diterima \\
\hline
\end{tabular}

\section{KESIMPULAN}

Klinik Smart Medica merupakan satu-satunya klinik terbesar di daerah Sekayu dan memiliki banyak pasien baik dari dalam daerah maupun dari luar daerah. Dengan dibangunnya Website ini masyarakat (user) menjadi lebih mudah mendapatkan informasi dari pihak Klinik Smart Medica Sekayu seperti informasi Jadwal Praktik Dokter sehingga user dapat mengetahui dokter-dokter yang sedang praktik pada hari itu maupun dokter yang diinginkan dan juga informasi-informasi lainnya. Dengan adanya informasi jadwal dokternyang akurat maka pasien dapat memilih waktu yang sesuai dengan jadwal dokter yang menangani penyakitnya dan juga tidak perlu menunggu lama di karenakan pada website tersebut sudah ada jam praktek doter nya.

\section{REFERENCES}

[1] D. Ferdiansyah, "Penerapan Konsep Model View Controller Pada Rancang Bangun Sistem Informasi Klinik Kesehatan Berbasis Web," $J$. Kaji. Ilm. Univ. Bhayangkara Jakarta Raya 195, vol. 18, no. 2, 2018.

[2] D. Indarti;Laraswati, "Rancang Bangun Sistem Informasi Pelayanan Kesehatan Berbasis Web Pada Klinik Umum Galur Medika Jakarta Pusat," BSI, vol. 4, no. 2, 2018.

[3] W. Chandra dan R. Amalia, "Sistem Informasi Pemesanan Kamar Mess Pt. Kai Persero Divre Iii Sumatera Selatan," CESS(Journal Comput. Eng. Syst. Sci., vol. 4, no. 1, hal. 88-93, 2019.

[4] A. Hendini, "Pemodelan Uml Sistem Informasi Monitoring Penjualan Dan Stok Barang (Studi Kasus: Distro Zhezha Pontianak)," J. Khatulistiwa Inform., vol. 4, no. 2, 2016.

[5] Sarwindah, "Sistem Pendaftaran Siswa Baru Pada SMP N 1 Kelapa Berbasis Web," SISFOKOM, vol. 7, no. 2, 2018.

[6] F. Nurlalela, "Aplikasi SMS Gateway Sebagai Sarana Penunjang Informasi Perpustakaan Pada Sekolah Menengah Pertama Negeri 1 Arjosari," Indones. J. Netw. Secur., vol. 2, no. 4, 2013.

[7] D. Wasistiono, Kapita Selekta Manajemen Pemerintahan Daerah. 2001.

[8] H. A. Cristian, Andi; Hesinto, "Rancang Bangun Website Sekolah Dengan Menggunakan Framework Bootstrap ( Studi Kasus SMP Negeri 6 Prabumulih )," SISFOKOM, vol. 7, no. 1, 2018.

[9] Wahana Komputer, SQL Server 2008 Express. Yogyakarta: Andi 
Offset, 2010

[10] I Putu Agus Yoga Permana, "Rancang Bangun Sistem Informasi Klinik Praktik Dokter Berbasis Web," J. Teknol. Inf. dan Komput., vol. 1, no. $2,2015$.

[11] Jenie Sundari, "Sistem Informasi Pelayanan Puskesmas Berbasis Web," IJSE - Indones. J. Softw. Eng., vol. 2, no. 1, 2016.

[12] A. Ahadi, "Sistem Informasi Pelayanan Kesehatan Pada Klinik Medika Antapani Bandung," Unikom Respository, 2016.

[13] D. S. Nugrahanto, "Pembuatan Sistem Informasi Pelayanan Kesehatan Masyarakat Berbasis Web Mapping (Studi Kasus: Kabupaten Sukoharjo, Provinsi Jawa Tengah)," Inst. Teknol. Nas. Malang, 2018

[14] I. Muhammad, "Pengembangan sistem informasi pelayanan kesehatan pada klinik dokter keluarga Suradita: studi kasus desa Suradita Kec.Cisauk Tangerang," Institutional Repos. UIN Syarif Hidayatullah Jakarta.

[15] S. Susilowati; dan B. K. Riast; "Pembuatan Sistem Informasi Klinik Rawat Inap Prima Husada Widoro Pacitan Berbasis Website," J. Sentra Penelit. Eng. dan Edukasi, vol. 3, no. 1, 2011.

[16] N. Huda, "Website Sistem Informasi Desa Sungai Rebo Banyuasin
Sumatera Selatan," in Konferensi Nasional Sistem Informasi, 2018, hal. $281-285$.

[17] R. Amalia dan N. Huda, "Sistem Informasi Pengarsipan Surat Masuk dan Surat Keluar Pada Dinas Tenaga Kerja dan Transmigrasi Kabupaten Musi Banyuasin,” Media Inform. Budi Darma, vol. 4, no. 2, hal. 363-368, 2020.

[18] N. Huda dan R. Amalia, "Implementasi Sistem Informasi Inventaris Barang pada PT.PLN (Persero) Palembang," J. Sisfokom, vol. 9, no. 1, hal. 13-19, 2020. 